Sumerianz Journal of Medical and Healthcare, 2022, Vol. 5, No. 1, pp. 1-8

$\operatorname{ISSN}(e):$ 2663-421X, ISSN(p): 2706-8404

Website: https://www.sumerianz.com

DOI: https://doi.org/10.47752/sjmh.51.1.8

(C) Sumerianz Publication

(). (1) CC BY: Creative Commons Attribution License 4.0

\title{
Knowledge, Attitudes and Practices of Dental Surgeon on Oral Cancer in Kinshasa City, Democratic Republic of the Congo
}

\section{Mfutu Mana Charly}

Service of oral and maxillofacial surgery, Department of Dental Medicine, Faculty of Medicine, University of Kinshasa, Kinshasa, Democratic Republic of the Congo, Congo Email: charlemfu@ gmail.com

\section{Sekele Issouradi Jean Paul}

Service of prosthodontics, Department of Dental Medicine, Faculty of Medicine, University of Kinshasa, Kinshasa Democratic Republic of Congo, Congo

Email: jp.sekele@unikin.ca.cd

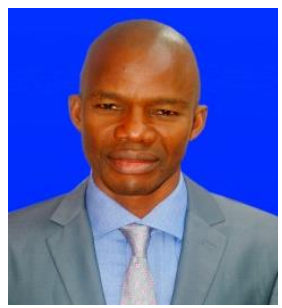

*(Corresponding author)

\section{Situakibanza Nani-Tuma Hippolyte}

Department of Internal Medicine, Department of Tropical Medicine, Faculty of Medicine, University of Kinshasa, Kinshasa, Democratic Republic of the Congo, Congo

Email: hsitua@gmail.com

\section{Nzudjom Foch Aderlin}

Service of oral and maxillofacial surgery, Department of Dental Medicine, Faculty of Medicine, University of Kinshasa, Kinshasa, Democratic Republic of the Congo, Congo

Email: nzudjomf@yahoo.fr

\section{Bolenge Ilebosso Jacques}

Service of oral and maxillofacial surgery, Department of Dental Medicine, Faculty of Medicine, University of Kinshasa, Kinshasa, Democratic Republic of the Congo, Congo Email: jacques.bolenge@unikin.ac.cd

\section{Paul Bobe Alifi}

Service of oral and maxillofacial surgery, Department of Dental Medicine, Faculty of Medicine, University of Kinshasa, Kinshasa, Democratic Republic of the Congo, Congo

Email: paulbobe2@gmail.com

\section{Sekele Marob Patrick}

Service of oral and maxillofacial surgery, Department of Dental Medicine, Faculty of Medicine, University of Kinshasa, Kinshasa, Democratic Republic of the Congo, Congo

Email: patrick.sekele@unikin.ac.cd

\section{Monizi Mawunu}

Polytechnic Institute of Kimpa Vita University, Uíge, Republic of Angola, Angola Email: m.mawunu2000@gmail.com

\section{Koto-Te-Nyiwa Ngbolua}

Department of Biology, Faculty of Science, University of Kinshasa, Kinshasa, Democratic Republic of the Congo, Congo

Email: jpngbolua@unikin.ac.cd

\section{Pakassa Muyulu Nestor}

Department of anatomy pathology, Faculty of Medicine, University of Kinshasa, Kinshasa, Democratic Republic of the Congo, Congo

Email: nestorpks2@gmail.com 


\title{
Article History
}

Received: 16 December 2021

Revised: 13 January 2022

Accepted: 19 January 2022

Published: 23 January 2022

\section{How to Cite}

Koto-Te-Nyiwa, Ngbolua. (2022). Knowledge, Attitudes and Practices of Dental Surgeon on Oral Cancer in Kinshasa City, Democratic Republic of the Congo. Sumerianz Journal of Medical and Healthcare, Vol. 5, No. 1, pp. 1-8.

\begin{abstract}
Background and aim: Oral cancer remains a public health problem with a high morbidity and mortality rate. The aim of this study was to determine the level of knowledge, attitude and practice of Kinshasa dentists on oral cancer. Patients and Method: This cross-sectional, descriptive study was conducted in public and private hospitals in the provincial city of Kinshasa between October 2019 and June 2020. A total of 143 dentists responded to the survey. The questionnaires included knowledge of risk factors, attitude and practice of Kinshasa dentists. Results: The average age of the participants was $34.05 \pm 7.31$ years, the male gender was the most represented $(69.2 \%)$, and the level of knowledge of the dentists about the risk factors was low despite the fact that the majority of the participants in the study had recognized alcohol $(77.5 \%)$ and tobacco (77.6\%) as the main risk factors for oral cancer. The majority of the participants referred the patient to a specialist upon discovery of a cancerous lesion, only a minority of dentists performed biopsy and counselling. Conclusion: The level of knowledge of Kinshasa's dentists about oral cancer is low. Refresher training is necessary to enable them to raise their level of knowledge. Thus, the reinforcement of cancer courses in the dental sector is important for a better management of cancer patient.
\end{abstract}

Keywords: Oral cancer; Knowledge; Practice; Kinshasa.

\section{Introduction}

Oral cancer is among the 10 most common cancers in humans [1]. 400,000 people had developed oral cancer in 2018 worldwide [2]. It affects all structures in the oral cavity. It is classified in the ICD classification between C003C014 [3]. Squamous cell carcinoma is the most common [4-6]. The etiology of these cancers is multifactorial. Smoking, alcohol consumption and human papillomavirus (HPV) infections are among the main risk factors for oral cancer $[6,7]$. Other risk factors are poor hygiene, chronic candidiasis, race, diet and nutrition [8-10]. leukoplakia is the principal precancerous lesion [11]. The majority of oral cancer occurs in people older than 50 years [12, 13]. The oral cavity is easily accessible for routine screening through clinical examination [14, 15]. Oral cancer is often discovered late in stages 3 and 4 of the disease $[16,17]$. Unfortunately, the delay to diagnosis patients with oral cancer is long and impact their survival $[16,17]$. In the Democratic Republic of Congo, the incidence of oral cancer is low at $1.8 \%$ [4]. One of the studies on the lethality conducted in Kinshasa University hospital has shown that $90 \%$ of oral cancer patients have less than one year of survival. The number of specialists in oral and/or maxillofacial surgery does not exceed 20 in the country. Dentists are the first practitioners to receive and follow up cancer patients in this huge country. Therefore, it is imperative that they know the different risk factors of oral cancer and their symptoms for a proper diagnosis [18-20]. Furthermore, taking a biopsy or judicious referral to specialist for suspicious lesions is beneficial [21,22]. The efforts are required for the prevention of oral cancer among the community medical and the population.

Dentists have the responsibility and the duty to improve their knowledge of oral medicine for the management of this tumor disease [23]. Much effort needs to be made in training to prevent this tumor disease through refresher courses, seminars and in the curriculum of oral science students [24, 25]. Several studies exist worldwide on the knowledge and practice of dentists regarding the oral cancer [13, 14, 22, 25-28]. Those studies demonstrated the real need to ameliorate the knowledge about the prevention and the detection of oral cancer. Nowadays, no study exists in the Democratic Republic of Congo upon the knowledge of dentists concerning the oral cancer.

The aim of this study was to determine the level of knowledge, attitude and practice of Kinshasa dentists on oral cancer.

\section{Material and Methods}

This is a cross-sectional, descriptive study carried out over a period of 8 months between October 2019 and June 2020 among dentists working in the public and private sectors in the provincial city of Kinshasa. 143 dentists were selected for this study. A survey form was developed and modified for the DRC context based on studies conducted in Saudi Arabia, Canada, Sudan, Ireland, [7, 12, 13, 24] and submitted to the ethics committee of the School of Public Health of the University of Kinshasa for approval. To avoid any interference, the investigators visited the various dental practices selected and interviewed the practitioners on site. An explanation of the purpose of the study was provided to the oral health care providers prior to the start of the survey, and an observation of their consultation practice was made prior to interviewing them. The questionnaires consisted of closed and open questions divided into three parts: 


\section{Sumerianz Journal of Medical and Healthcare}

- The first part included socio-demographic factors of the dentists (gender, age, qualification, professional experience).

- The second part included risk factors and different methods of diagnosis and treatment of oral cancer with answers (yes, no)

- The third part concerned the attitude, practice and level of knowledge of Kinshasa's dentists regarding the risk factors of oral cancers. 10 questions were used. Each question was given one point. Then we added up the correct answers to calculate the index of knowledge about risk factors.

\section{Results}

Table-1. Characteristic of dentists who participated in the oral cancer study

\begin{tabular}{|c|c|c|}
\hline \multicolumn{3}{|l|}{$n=143$} \\
\hline Variable & Frequency & Percentage \\
\hline \multicolumn{3}{|l|}{ Gender } \\
\hline Male & 99 & 69,2 \\
\hline Female & 44 & 30,8 \\
\hline \multicolumn{3}{|l|}{ Age } \\
\hline 20-29 years & 54 & 37,8 \\
\hline 30-39 years & 66 & 46,2 \\
\hline 40-49 years & 17 & 11,9 \\
\hline $50-59$ years & 4 & 2,8 \\
\hline 60 years and more & 2 & 1,4 \\
\hline \multicolumn{3}{|l|}{ Professional experience } \\
\hline $1-5$ years & 96 & 67,1 \\
\hline 6-10 years & 36 & 25,2 \\
\hline 11-15 years & 4 & 2,8 \\
\hline 16-20 years & 4 & 2,8 \\
\hline 21-25 years & 2 & 1,4 \\
\hline 26 years and more & 1 & 0,7 \\
\hline \multicolumn{3}{|l|}{ Post-graduate training } \\
\hline Yes & 36 & 25,2 \\
\hline No & \begin{tabular}{|l}
107 \\
\end{tabular} & 74,8 \\
\hline
\end{tabular}

A total of 143 dentists participated in this survey.

The majority of the participants were male (69.2\%), the average age of the participants was $34.05 \pm 7.31$ years. The majority of the dentists $(67.1 \%)$ had $1-5$ years of experience.

$74.8 \%$ had not received any training or refresher courses after their university studies.

$53.8 \%$ of the dentists were aware of genetics as a risk factor for oral cancer.

Ionizing radiation (sun exposition) was not recognized by the majority of participants as a risk factor (87.4\%).

$86 \%$ of the dentists did not know that HPV (Human Papilloma Virus) was a risk factor for oral cancer.

The majority of dentists did not know poor oral hygiene as a risk factor $(72.7 \%) .77 .5 \%$ of the dentists knew alcohol as a risk factor.

$77.6 \%$ of the dentists were aware of smoking (tobacco) as a risk factor.

$90,2 \%$ of the dentists were not aware that advanced age can be risk factors for oral cancer.

$70 \%$ of the dentists had no knowledge of leukoplakia a as risk factors for oral cancer.

The majority of the participants $(72 \%)$ had no idea about chronic trauma as a risk factor. 


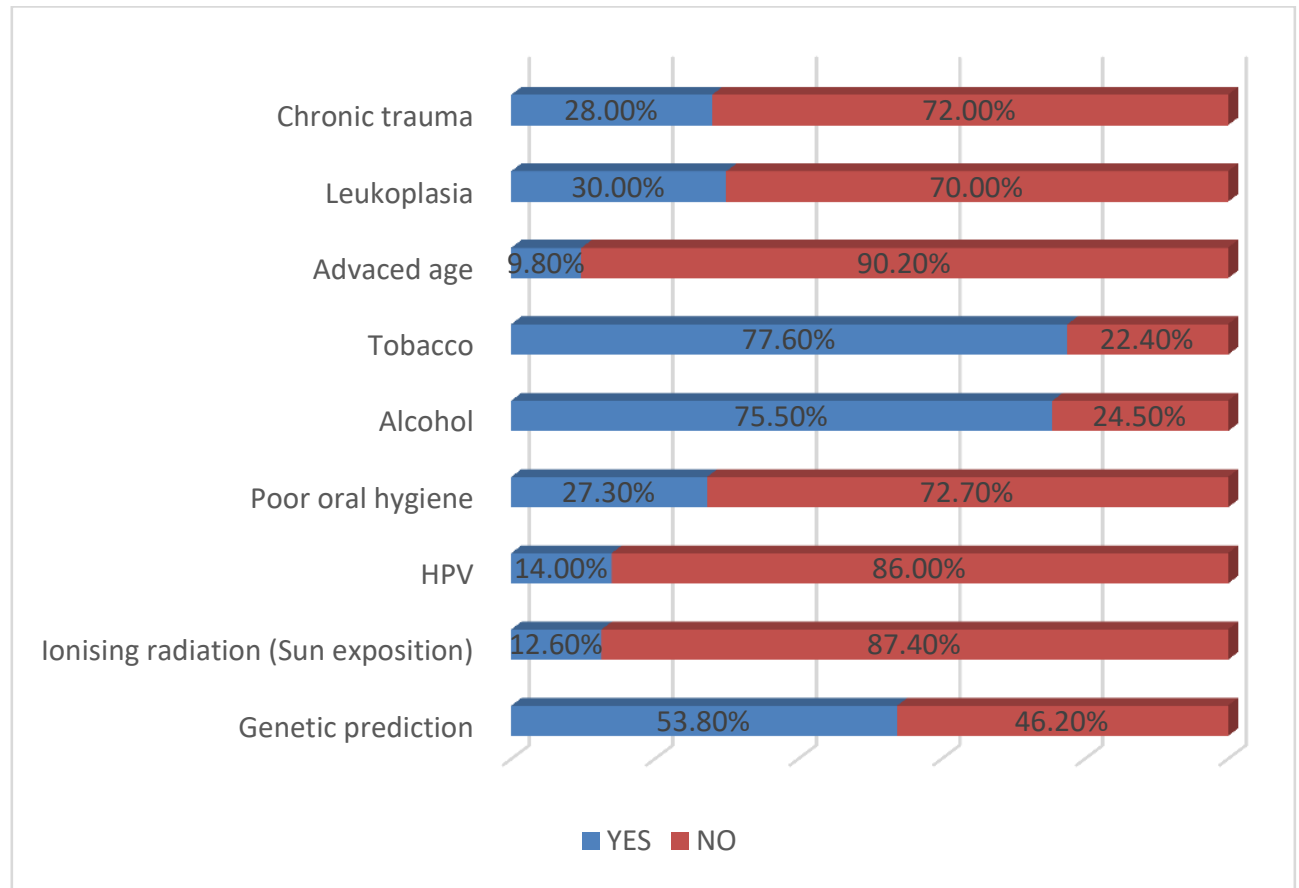

Fig-1. Identification of risk factors for oral cancer

Regarding treatment, only a minority of dentists were aware of the different treatments for oral cancer $(46.2 \%$ for surgery and chemotherapy; $37.1 \%$ for psychotherapy; $24.5 \%$ for palliative treatment).

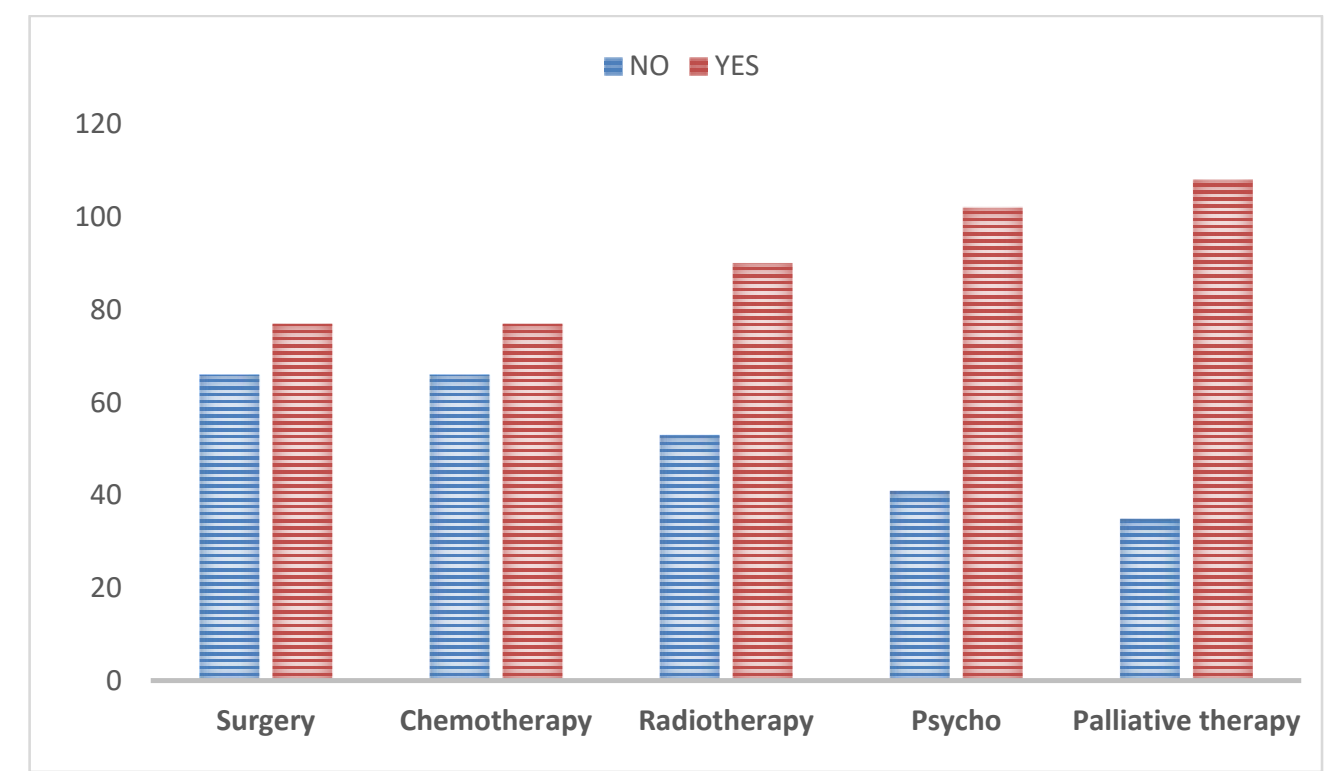

Fig-2. Knowledge of oral cancer treatment

Table-2. Knowledge of the different average of diagnostics of oral cancer

\begin{tabular}{l|l|l|l}
\hline $\mathrm{n}=143$ & & Frequency & Percentage \\
\hline Variable & & & \\
\cline { 2 - 4 } & Yes & 72 & 50,3 \\
\cline { 2 - 4 } & No & 71 & 49,7 \\
\hline \multirow{3}{*}{ Molecular biology } & & & \\
\cline { 2 - 4 } & Yes & 3 & 2,1 \\
\cline { 2 - 4 } & No & 140 & 97,9 \\
\hline \multirow{3}{*}{ Cytology } & & & 0,7 \\
\cline { 2 - 4 } & Yes & 1 & 99,3 \\
\cline { 2 - 4 } & No & 142 & \\
\hline
\end{tabular}

Regarding the average of diagnosis, half of the participants (50.3\%) in the study knew biopsy as a means of diagnosis, $97.9 \%$ had no knowledge of molecular biology and $99.3 \%$ did not know cytology as a means of diagnosis. 
Table-3. Attitudes and practice of dentists on oral cancer

\begin{tabular}{|c|c|c|c|}
\hline \multicolumn{4}{|l|}{$n=143$} \\
\hline Dentists' attitudes to cancer & & Frequency & Percentage \\
\hline Oral cancer training & $\begin{array}{l}\text { Yes } \\
\text { No }\end{array}$ & $\begin{array}{l}4 \\
139\end{array}$ & $\begin{array}{l}2,8 \\
97,2\end{array}$ \\
\hline Biopsy practice & $\begin{array}{l}\text { Yes } \\
\text { No }\end{array}$ & $\begin{array}{l}26 \\
117 \\
\end{array}$ & $\begin{array}{l}18,2 \\
81,8\end{array}$ \\
\hline $\begin{array}{l}\text { Refer to a specialist if a cancerous } \\
\text { lesion is found? }\end{array}$ & $\begin{array}{l}\text { YesN } \\
\mathrm{o}\end{array}$ & $\begin{array}{l}101 \\
42 \\
\end{array}$ & $\begin{array}{l}70,6 \\
29,4 \\
\end{array}$ \\
\hline $\begin{array}{l}\text { Do you talk to your patients about } \\
\text { cancer? }\end{array}$ & $\begin{array}{l}\text { Yes } \\
\text { No }\end{array}$ & $\begin{array}{l}44 \\
99 \\
\end{array}$ & $\begin{array}{l}30,8 \\
69,2 \\
\end{array}$ \\
\hline $\begin{array}{l}\text { Palpate yourself: } \\
\text { Nodes } \\
\text { Lip and oral mucosa } \\
\text { Tongue }\end{array}$ & $\begin{array}{l}\text { Yes } \\
\text { No } \\
\text { Yes } \\
\text { No } \\
\text { Yes } \\
\text { No } \\
\end{array}$ & $\begin{array}{l}32 \\
111 \\
32 \\
111 \\
32 \\
111 \\
\end{array}$ & $\begin{array}{l}22,4 \\
77,6 \\
22,4 \\
77,6 \\
22,4 \\
77,6 \\
\end{array}$ \\
\hline $\begin{array}{l}\text { Do you do the counseling } \\
\text { On Tobacco? } \\
\text { On alcohol? }\end{array}$ & $\begin{array}{l}\text { Yes } \\
\text { No } \\
\text { Yes } \\
\text { No }\end{array}$ & $\begin{array}{l}51 \\
92 \\
56 \\
87\end{array}$ & $\begin{array}{l}35,7 \\
92,3 \\
39,2 \\
60,8 \\
\end{array}$ \\
\hline $\begin{array}{l}\text { Ask about your family history of } \\
\text { cancer? }\end{array}$ & $\begin{array}{l}\text { Yes } \\
\text { No }\end{array}$ & $\begin{array}{l}16 \\
127 \\
\end{array}$ & $\begin{array}{l}11,2 \\
88,8 \\
\end{array}$ \\
\hline
\end{tabular}

$2.8 \%$ of the participants had training in oral cancer.

$18,2 \%$ of respondents practiced a biopsy

$70.6 \%$ of dentists would refer patients after a cancerous lesion was found.

$77.6 \%$ of the dentists did not routinely palpate nodes, mucous membranes, tongue, mucous membranes during their routine consultation.

$35.7 \%$ of dentists performed tobacco counselling.

$39.2 \%$ of dentists practiced alcohol counselling.

Only $11.2 \%$ of the dentists asked about the family history and cancer history of the patients.

Table-4. Percentage distribution of dentists by general profile of knowledge about oral cancer risk factors

\begin{tabular}{l|l|l}
\hline & Frequency & Percentage \\
\hline Mediocre (0-3 questions) & 39 & 27,3 \\
\hline Low (4-6 questions) & 98 & 68,5 \\
\hline Good (7-10questions) & 6 & 4,2 \\
\hline Total & $\mathbf{1 4 3}$ & $\mathbf{1 0 0 , 0}$ \\
\hline
\end{tabular}

The majority of dentists had a low level of knowledge of oral cancer risk factors.

\section{Discussion}

It is necessary for dentists to know the different risk factors and the different methods of diagnosis of oral cancer for a suitable management and reducing the morbidity and mortality linked to this pathology [13, 14, 25, 27]. This study carried out in the city of Kinshasa allowed us to know the current state of knowledge of dental surgeons on oral cancer.

The majority of participants in this study were male (69.2\%). Our results were consistent with studies conducted in Egypt, Yemen, Nigeria and Kuwait [21, 26, 28, 29] but different from the Sudanese study where the majority of participants were female [12]. This reflects the reality of sub-Saharan countries where the world of work is still dominated by men [30]. The age group between 30-39 years was the most represented, which corroborates the studies conducted in Qatar and Saudi Arabia [7,31]. This situation reflects the demographic curve of African countries where the majority of the population is young, unlike in the West where the profession is ageing in line with the population curve [32]. Although the vast majority of participants in this study were able to identify alcohol $(77,5 \%)$ and tobacco $(77,6 \%)$ as the main risk factors for oral cancer. Previous studies conducted in other countries have shown similar results [12, 13, 21,31]. Indeed, alcohol and tobacco contain carcinogens that strongly contribute to the development of oral cancer [33,34], hence the major importance of involving dentists in tobacco and alcohol control program to reduce the mortality and morbidity of oral cancer. Genetic predisposition was also identified as a risk factor by the majority of dentists $(53.8 \%)$. Indeed, in populations where all members were exposed to the same carcinogenic xenobiotic, some develop cancers and others do not [23,34]. Only, a minority of dentists $(9,8 \%)$ correctly identified advanced age as a potential risk factor for oral cancer. This differs from studies in Qatar, Canada, Sudan where dentists clearly identified these factors $[12,13,31]$. The majority of dentists $(76 \%)$ incorrectly identified Human Papilloma virus as a risk factor for oral cancer. Similar results to previous studies conducted in 


\section{Sumerianz Journal of Medical and Healthcare}

Yemen, Jordan, Japan [20, 26, 35]. Human papilloma virus one is an important factor in the development of oral cancer and pre-malignant lesions such as oral papilloma Florida [36]. A smaller percentage of dentists were aware that Ionizing radiation (sun exposition) in the case of potential risk factor for oral cancer. This differs from studies in United Arab Emirates, Turkey [37, 38]. Sun exposition plays an important role in the development of lip cancer [14, 37, 38]. Around $30 \%$ of participants in this study recognized premalignant lesion (leukoplakia) as a risk factor for oral cancer. Several studies correctly identified leukoplakia as the principal precancerous lesion associated with oral cancer [20, 26, 31]. A small proportion of dentists (27,3\%) indicated correctly the poor oral hygiene was a risk factor for oral cancer. These results were comparable to the findings in similar studies conducted in Iran and Irish [39, 40]. But some authors do not consider oral hygiene a risk factor [31, 41]. But in this study, oral hygiene was considered a risk factor for oral cancer. The majority of dentists in Kinshasa had little knowledge of the different treatment options for oral cancer. 50, 3\% of dentist recognized biopsy a means of diagnosis for oral cancer. The result of study is similar trend to a Nepal and Iran studies [22, 42]. In this study, regarding the level of general knowledge profile on risk factors only a small minority of dentists had a satisfactory level of knowledge. As oral/precancer can be prevented by controlling risk factors such as the use of tobacco and the consumption of alcohol [26, 43]. In this study, only a minority of dentists reported that practice tobacco use-cessation $(35,7 \%)$ and alcohol-abuse $(39,2 \%)$ counseling, which differs from studies in Ireland, Yemen and Qatar [19, 26, 31]. In the present study, 22, 4\% of respondents palped nodes, tongue, lips and oral mucosa. These results differ from those found in several studies conducted in Jordan, Egypt and Turkey [21,38]. 11, 2\% of dentists asked the family history of cancer. A smaller percentage that reported in comparable studies elsewhere [26, 44, 45]. Regarding diagnosis means, only 18,2\% of dentists had practiced biopsy in the study. These results were similar to those reported in a study carried out in Nepal [22]. $70,2 \%$ of the participants would refer patients to a specialist if a cancerous lesion was found, which corroborates the Sudanese study [12]. A smaller percentage of Dentists $(2,8 \%)$ had training in oral cancer. These results were in contrast with a study conducted in Egypt Khattab, et al. [21]. The need for continuous medical education is also increased by changes in scientific knowledge, advances in tools for early detection and changes in the pattern of oral cancer incidence that is associated with emerging risk factors $[26,46]$.

The capacity building of dental practitioners in cancer care is crucial for the proper management of cancer patients. Therefore, special attention should be paid to the training of Kinshasa dentists on oral cancer. Indeed, a good knowledge of oral cancer among dentists could improve the quality of life of cancer patients and increase their chances of survival.

\section{Conclusion}

Gaps in the knowledge of Kinshasa's dentists about oral cancer were revealed through this study. There is a need to upgrade the knowledge of dentists on oral cancer. Refresher training, continuing education and the reinforcement of education on oral cancer and precancerous lesions are essential for the proper management of oral cancer patients.

\section{References}

[1] FDI, 2018. "Oral Cancer prevention and patient management." Available: www.fdiworlddental.org

[2] Freddie, B., Jacques, F., Isabele, S., Rebecca, L. S., Lindsey, A. T., and Ahmedin, J., 2018. "Global cancer statistics globocan estimates of estimates of incidence and mortality worldwide for 36 cancers in 185countries CA." Cancer Clin., vol. 68, pp. 394-424.

[3] CIM-10-Fr, 2019. Available: www.who.int/classifications/icd/iccd/icd/10updates.consultéle

[4] Charly, M., Nestor, M. P., Jean-Paul, I. S., Adelin, F., Nzudjom, Jacques, I. B., Dieudonne, C., NYembwe, and Koto-te-Nyiwa, 2019. "Evaluation of oral cavity cancers frequency in patients attending dentistry and maxillofacial surgery service of Kinshasa university hospital (democratic republic of the Congo):A CrossSectional study." International Journal of Applied Dental Sciences, vol. 5, pp. 293-296.

[5] Kumar, K. V., Surresan, V., and knowledge, 2012. "Attitude and screening pratices of general dentists concerning oral cancer in bangalore city." Indian J. Cancer, vol. 49, pp. 33-38.

[6] Paré, A. and Joly, A., 2019. "Cancers de la cavité buccale: Facteurs de risqué et prise en charge.J?PLM 2017;46(3):320-30.Zanoni DK,Montero PH, Migliacci JC, et al. Survival outcomes after treatment of cancer of the oral cavity (1985-2015)." Oral Oncol., vol. 90, p. 11521.

[7] Kazim, F., Alkait, S., Alghamdi, H., Alhussain, G., and Tabassum, A., 2020. "Assessing knowledge,attitude and practices for oral squamous cell carcinoma among health care professionals in princess nourah university, riyadh, KSA." Asian Pac J. Cancer Prev., vol. 21, pp. 539-545.

[8] Dhanuthai, K., Rojanawatsirivej, S., Thosaporn, W., Kintarak, S., Subarnbhesaj, A., Darling, M., and Kryshtalskyj, E., 2018. "Oral Cancer: A multicenter studfy." Med Oral Patol Oral Cir. Bucal., vol. 23, pp. e23-9.

[9] Mustafa, E., Parmar, S., and Praveen, P. Premalignant lesions and condition of the oral cavity in Bonanthaya k, PanneerSelvam E, Manuel S, Kumar V.V, Rai A.(eds).oral and Maxillofacial surgry for the clinician. Singapore: Springer.

[10] Tenore, G., A., N., Mohsen, A., and Cassoni, A., 2020. "Tobacco, alcohol and familly history of cancer as risk factors of oral squamous cell carcinoma: Case-control retrospective study." Appl. Sci., vol. 19, p. 3896.

[11] Wanakanasuriya, S. and Ariyawardana, A., 2016. "A Malignant transformation of oral leukoplakia:a systematic review of observational studies." J. Oral Pathol Med., vol. 45, pp. 155-166.

[12] Ahmed, N. H. M. and Naidoo, S., 2019. "Oral cancer knowledge, attitudes and practices among Dentists in Khartoum state, Sudan." J. Cancer. Educ., vol. 34, pp. 291-296. 


\section{Sumerianz Journal of Medical and Healthcare}

[13] Aldossri, M., Okoronkwo, C., Manson, H., and Singhal, S., 2020. "Dentist's capacity to migate the burden of oral cancers in Ontario, Canada." J. Can. Dent. Ass., vol. 86, p. K1.

[14] Coppola, N., Mignogna, M. D., Riveccio, I., and Bizzoca, M. E., 2021. "Knowledge, attitudes, and pratice among health care providers inoscc awareness: Systematic review and meta (analysis)." Int. J. Environ. Res. Public Health, vol. 18, p. 4506.

[15] Poh, C. F., Williams, M., Zhang, L., and Miriam, F. R., 2006. "Attention! Appel Aux Dentistes pour le Dépistage du cancer de la Bouche." J. Can. Dent. Assoc., vol. 72, pp. 413-6.

[16] Brito, R. T., Perazzo, M. F., and Peixoto, T. S., 2018. "The clinical staging of oral cancer squamous cell carcinoma." Rev. Salud. Publica., vol. 20, pp. 221-225.

[17] Zanoni, D. K., Montero, P. H., Migliacci, J. C., Shas, J. P., and Wong, R. J., 2019. "Survival outcomes after treatment of cancer of oral cavity (1985-2015)." Oral Oncology, vol. 90, pp. 115-21.

[18] Clovis, J. B., Horowitz, A. M., and Poel, D. H., 2002. "Cancers de la bouche et du pharynx: Connaissances et Opinions des Dentistes de la Colombie-Britannique et de la Nouvelle-Écosse." J. Can Dent Assoc., vol. 68, pp. 415-20.

[19] Decuseara, G., Mac, C., and Menezes, G., 2011. "Oral cancer:knowledge;practices and opinions of Dentists of Ireland." J. Ir. Dent. Assoc., vol. 57, pp. 209-2014.

[20] Hassona, Y., Scully, C., A., S., Maayta, W., and Sawair, F., 2016. "Factors influencing early detection of oral cancer by primary health-care professionals." J. Cancer Educ., vol. 31, pp. 285-291.

[21] Khattab, N. M. A., ELheeny, A. A. H., and Tony, G. A., 2019. "Oral-cancer knowledge, practice and attitude assessment of dentist in Upper Egypt: A cross-sectional study." Clin. Exp. Res., vol. 5, pp. 121-127.

[22] Shrestha, B. and Subedi, S., 2020. "Knowledge, attiyude and practice of oral biopsy. Procedures among dental surgeons registered with nepal dental association." Journal of Nepal Dental Association, Journal of Nepal Health Research Council, vol. 18, pp. 70-74.

[23] Gauzeran, D., 2007. lésions à risque et cancers de la boucle. Du diagnostic au traitement. Editions Cdp, p. 151.

[24] Horowitz, A. M., Drury, T. F., Goodman, H. S., and Yellowitz, J. A., 2000. "Oral pharyngeal cancer prevention and early detection. Dentists' opinions and practices." J Am. Dent Assoc., vol. 131, pp. $453-62$.

[25] Silverman, S. J. R., Kerr, A. R., and Epsteing, J. B., 2010. "Oral and pharyngeal cancer control and Early detection." J .Cancer. Educ., vol. 25, pp. 279-81.

[26] Alaizari, N. A. and Al-Maweri, S. A., 2014. "Oral cancer: knowledge, practices and opinions of Dentists in Yemen." Asian Pac J Cancer Prev., vol. 15, pp. 5627-5631.

[27] Alqhatani, N., Alenazi, A., Nasyam, F. A., Almalki, S. A., and Mohammed, A., 2019. "Role of the dentist in early detection of oral cancer." J. Int. Oral Health, vol. 11, pp. 66-69.

[28] Gbotolorun, O. M., Ayodele, A. S., Olojede, A. C., Adamson, O. O., Emeka, C. I., and Amao, A. T., 2014. "Knowledge and screening practices for oral cancers amongst general dental practitioners in Lagos, Nigeria." Afr. J. Biomed Res., vol. 17, pp. 69-73.

[29] Nazar, H., SHyama, M., Arigu, J., El-Salhy, M., Soparkar, P., and Alsumait, A., 2019. "Oral cancer knowledge, attiudes and practices among primary oral health care dentists in Kuwait." Asian Pac. J. Cancer Prev., vol. 20, pp. 1531-1536.

[30] Les Femmes Au Travail, 2016. Tendances, Available: www.ilo.org.Consulted:2/3/2021

[31] Jboor, D. H., Al-Darwish, M. S., and Nur, U., 2019. "Oral cancer knowledge, Attitude and practice of Dentists in the state of Qatar." Dent. J., vol. 7, p. 43.

[32] Khokhar, T. "Graphique : Les populations les plus jeunes sont en Afrique." Available: https://blogs.worldbank.org/fr.Consulted:20/3/2021

[33] Mir, F. Q., Santosh, K. T., and Tenny, J., 2019. "Smokeless tobacco and oral cancer in the middle east and north Africa: A systematic review and meta-analysis." Tob. Induc. Dis., vol. 17, p. 56.

[34] Monteil, R. A., 2005. "Tabagisme, génétique et cancer buccal." J. Dent. Québec., vol. 42, pp. 323-326.

[35] Kogi, S., Dasilva, J., Mikasa, Y., Lee, C., and Ishikawa-Nagai, 2019. "Knoweledge and practice of oral cancers screening in Teaching Faculty-Comparisonof speciality and year of clinical Experience." J. Cancer Educ., vol. 34, pp. 455-462.

[36] Krane, J. F., 2013. "Role of cytology in the diagnosis and management and of HPV-associated head and ceck carcinoma." Act Cytol., vol. 57, p. 1176126.

[37] Hashim, R., Abo-Fanas, A., Al-Tak, A., Al-Kadri, and Abu Ebaid, Y., 2018. "Early Detection of Oral cancer-Dentists'knoweldge and practices in the united arab emirates." Asian Pac. J. Cancer Prev., vol. 19, pp. 2351-2355.

[38] Kebabcioglu, O. and Pekiner, F. N., 2018. "Assessing oral cancer awareness among dentistd." J. Cancer Educ., vol. 33, pp. 1020-1206.

[39] Ni Riordain, R. M. C. and Creary, C., 2009. "Oral Cancer -current knowledge, practices and implications for training among Irish general medical practionner cohort." Oral Oncol., vol. 45, pp. 958-962.

[40] Razzavi, S. M., Zolfaghari, B., Foroohandeh, M., Doost, M. E., and Tahani, B., 2013. "Dentists' knowledge , attitude, and practiceregarding oral cancer in Iran." J. Cancer Educ., vol. 28, pp. 335-341.

[41] Gbotolorun, O. M., Ewaka, O., Lawal, A., Faday, I. O., and Emeka, C. I., 2015. "Knowledge, opinions, and practices about oral cancer among general medical practitioners in Lagos, Nigeria." J. Oeal Res. Rev., pp. 611 . 
[42] Keshani, F., Razavi, S. M., and Jalalpour, N., 2021. "Knowledge,attitude and pratice general dentists and dental students of is fahan university about the principes of biopsy." J. Isafhan Dent. Sch., vol. 17, pp. 273 282.

[43] Gustavo, G. D. and Ostroff, J. S., 2005. "Preventing and detecting Oral cancer:Oral Health care providers'readiness to provide health behavior counseling and Oral cancer examinations." J. AM. Dent. Assoc., vol. 136, pp. 595-682.

[44] Anandani, C., Metgud, R., Ramesh, G., and Singh, K., 2015. "Awareness of General Dental Practitioners about screening and Biopsy procedures in Udaipur, India." Oral Health Prev. Dent., vol. 13, pp. 523-530.

[45] Pavao, S. G., Salgado, de Souza, R., Gallego, A., Pecorari, V., and Lauria, D. L., 2018. "Oral cancer knowledge assessment : Newly graduated versus senior dental clinicians." Int. J. Dentistry., Available: https;//doi.org/10.1155/2018/9368918

[46] Lehew, C. W., Epstein, J. B., Kaste, L. M., and Choi, Y. K., 2010. "Assessing oral cancer early detection :clarifying dentists' practices." J. Public. Health Dent., vol. 70, pp. 93-100. 